\title{
Corporate Social Responsibility (CSR): Case Study in UAE and Community Expectations
}

\author{
Dr. Najeb Masoud ${ }^{1}$, Dr. Om Prakash Bohra ${ }^{2}$ \\ ${ }^{1,2}$ School of Business Administration, Al Dar University College, Dubai-United Arab \\ Emirates
}

\begin{abstract}
The purpose of this paper is to provide a practical review of topical developments in corporate social responsibility (CSR) practices under the influence of UAE community expectations. To investigate the concept of CSR in UAE, this paper primarily draws on secondary sources including extant literature on CSR practices, government reports, industry reports, companies' CSR/sustainability reports, newspaper articles, and publications of international agencies. The findings of this paper reveal that the concept of CSR is relatively underdeveloped in UAE. There is a general perception among community expectations and business practitioners in UAE that CSR relates to altruism or philanthropic activities. However, only few large local companies and multinational enterprises hold a well-defined CSR policy. Small and medium enterprises limit their CSR engagement to comply with codes of conduct set by foreign purchasers. The discussion in this paper is based on the secondary data; therefore, the empirical research is needed to validate the findings of this study. Further, this research presents a generic reflection about how CSR is practiced and perceived in UAE community expectations. Thus, the limited number of researches in UAE on CSR provides opportunity for further research in different theoretical perspectives and sectors.
\end{abstract}

Keywords: Corporate social responsibility (CSR); Review paper; Community expectations; Social sustainability; United Arab Emirates (UAE) 


\section{Introduction}

The current belief that corporations have a responsibility towards society is not new. In fact, the idea that businesses should voluntarily contribute to the well-being of the communities where they operate dates back far into the 19th century, the scientific discussion of that phenomenon began in the 1930s. Although, significant references to a concern for social responsibilities appeared during the 1930s and 1940s (Moon \& Parc,

2019). the key term "social responsibility" was finally introduced in 1953 by Howard Bowen in his path-breaking work social responsibilities of the businessman (Bowen, 1953). Today, more than 50 years after its introduction by Bowen, "corporate social responsibility" (CSR) has become a highly popular term among scholars and practitioners alike, and are considered sine-qua-non for competitive advantage and long-term sustainability (Halme \& Laurila, 2009; Brik et al., 2010; Carroll \& Shabana, 2010; Blomgren, 2011; Masoud, 2017).

Various reviews of CSR practices have been published over the last decade, including general reviews (e.g., Aguinis \& Glavas, 2012) and narrower reviews of specialist areas such as theories of CSR, business case for CSR, and political CSR (e.g., Secchi, 2007; Carroll \& Shabana, 2010; Frynas \& Yamahaki, 2016; Parker, 2018). The insights and conclusions drawn from some authors of long standing in terms of diagram "what we know and don't know about CSR" (Aguinis \& Glavas 2012, p. 932), but the unique elements of CSR in developing countries have been referred to in the literature, with CSR commonly characterized as less formalized, and more philanthropic in nature (Visser, 2008; Jamali \& Karam, 2018). Further augmenting the need to explore CSR in developing countries are the various arguments against the transferability of frameworks and conclusions drawn in developed countries to those that are developing (Blowfield \& Frynas, 2005; Moon \& Shen, 2010; Idemudia, 2011). The latter arguably lack comprehensive review studies that explore the existing body of literature related to the CSR practices (Walter \& Sharyn, 2017).

Despite this growing interest in CSR in the United Arab Emirates (UAE) organizations, there is lack understanding of different national interests in CSR practices of this literature to date. Our aim in the current paper is to document how this literature community expectation with and contributes to the wide scope literature on CSR. Our focus is on two important research questions, namely: 1) how CSR in UAE organizations is commonly understood and 2) in what ways is CSR expressed and implemented in practice in UAE organizations. In other 
words, our review of this literature seeks to determine what has been found to be distinctive about perceive CSR in UAE country as a domain of study.

Our paper makes the following important contributions. First, we develop a comprehensive and interdisciplinary review of the specific body of literature on CSR in UAE country, and situate our analysis within the broader CSR and management literature. Second, based on this review, we identify key themes and insights from the past decades and the differentiating attributes of this body of research as a distinctive field within the CSR practices. Third, in the final section, we consolidate the main distinctive themes, identify lingering gaps, and provide relevant guidance for future research.

\section{Literary Review}

The meaning of CSR has a long and adverse history in the literature (Carroll, 1999), dogging the debate from the beginning (Frederick, 2006). Although sixty years of a fruitful debate, the sole agreement within academia about a CSR definition is the concurrence that the task is inherently difficult (Jackson \& Apostolakou, 2010; Grafström \&Windell, 2011), and there is no universal definition of CSR (Lockett, et al., 2006; McWilliams et al., 2006; Blowfield \& Murray, 2008; Aguinis \& Glavas, 2019), or leading conceptual framework (Carroll, 1999). Beyond the aforementioned academics, Falck \& Heblich (2007) were found to consider CSR a voluntary corporate commitment which exceeds explicit and implicit societal expectations of organizations behavior. Therefore, organizations now realize that in order to survive and stay unique in business and obtain strategic advantages; they need to practice being socially responsible while doing business and making profits.

Supporting Quazi \& O’Brien (2000) perceive CSR as a universal concept, literature identifies variations across countries (Welford, 2004; Egri \& Ralston, 2008; Ardichvili et al., 2012; Chomvilailuk \& Butcher, 2013).

Visser (2008 in Jamali \& Neville, 2011, p. 601) believed that CSR in developing countries has been characterized as more "extensive than commonly believed, less embedded in corporate strategies and less politically rooted than in most high income countries". In this regard, Blowfield \& Frynas (2005, p. 503) suggest an extended conceptualization of CSR concept in the developing countries as an umbrella term for a variety of theories and practices including: 
1. that companies have a responsibility for their impact on society and the natural environment, sometimes beyond legal compliance and the liability of individuals;

2. that companies have a responsibility for the behavior of others with whom they do business (e.g., within supply chains); and

3. that business needs to manage its relationship with wider society, whether for reasons of commercial viability or to add value to society.

Overall the literature clearly indicates that regardless of there being one general agreedupon the concept of CSR, most explanation illustrate a consensus which tends to depict CSR to include organization going beyond financial goals, taking into account the interests of varied stakeholders, on a voluntary basis. As such, this study appreciates Bentele \& Nothhaft (2011) belief that CSR is simultaneously about corporations acting responsibly as well as the perception of the society.

\subsection{Keywords, databases and literature}

Despite the wide literature on CSR, meanings, application and interpretation appears to differ from one context to another (Kang \& Moon 2011; Masoud, 2017). De Bakker et al. (2006) identified relations between CSR and the broad literature on comparative capitalism and set the attitude for comparative institutional research on CSR (as cited in Matten \& Moon, 2008; Jackson \& Apostolakou, 2010; Ruggiero et al., 2018). For instance, they posed the now well-known question asking why CSR is an implied element of the institutional framework of corporations in Europe, whereas it is a clear element of corporate policies in the U.S. The idea of CSR in the Europe was first mentioned in 1993 by the President of the European Commission, and the concept of CSR was accepted by the European Council in Lisbon in 2000 (Metaxas \& Tsavdaridou, 2010). Therefore, a large of the research on CSR has been conducted in the developed world (e.g., North America \& Europe) but interest is now growing in larger emerging countries as well (Aguinis \& Glavas, 2012; Karam \& Jamali, 2017). In addition, there is a lack on how CSR is to be understood, practiced and evaluated across different cultures globally (Matten \& Moon, 2008; Diehl et al., 2016; Fifka, 2013; Ruggiero et al., 2018). Consequently, we lack understanding of different national interests in CSR practices, viewpoints and identities. In other words, there is a scarcity of understanding on how the responsibilities of companies and various actors are creating in 
different institutional and national settings of business organization and community expectations. In order to address this deficiency this study focuses the CSR practices in UAE.

\subsection{Theoretical foundations of CSR Dimensions}

The definition of CSR was shaped into theory, research and practice many years ago. Since the later 1950s and early 1960s, CSR has attracted attention from a range of businesses and stockholder (De George, 2011). When Howard Bowen provided a first vague definition of CSR in 1953, he stated that it "refers to the obligations of businessmen to pursue those policies, to make those decisions, or to follow those lines of action which are desirable in terms of the objectives and values of our society" (Bowen, 1953). His argument was that the purpose of social responsibility is not so much to solve problems in businesses and society, but rather to act as a mechanism to assist businesses. Bowen is largely credited in CSR literature as being "the father of CSR" (Carroll, 1999). All other definitions in the early 50s recognise the need for managers to assume responsibility for public good "it has to consider whether the action is likely to promote the public good, to advance the basic beliefs of our society, to contribute to its stability, strength, and harmony" (Drucker, 1954).

Authors such as Davis, McGuire and Walton were among the early academics who offered definitions of CSR in the literature. Davis (1973) points out two original ideas on this issue of CSR's relevance to the viability of business; first that "Society gave business its charter to exist, and that charter could be amended or revoked at any time that business fails to live up to society's expectations", and his idea which ties in with the social contract theory, and the concession corporate theory, and second that "if business wishes to retain its present social role and social power, it must respond to society's needs and give society what it wants (Davis, 1973, p.34). McGuire (1963) believed that organizations' responsibilities towards society are beyond the economic and legal expectation, but Davis

\& Blomstrom (1975) identified individual's character as a main contributor to social responsibility. On other hand, Walton (1967) preferred voluntarism over coercion. The European Commission makes same argument with Walton, as it states that companies subscribing to CSR integrate social environmental concerns in their business operations and interact with their stakeholders on a voluntary basis. 
The concept and definition of CSR is not an easy task, and a lack of consensus exists on the contents of CSR practices (Dahlsrud, 2008; Dobers, 2009; Carroll \& Shabana, 2010; Taneja et al., 2011; Masoud, 2017; El Akremi et al., 2018), and for this reason definition of CSR have diverse widely. For instance, Moon et al. (2005), and Matten \& Moon (2008) identifies three major reasons for this complexity. First, this is because CSR is an "essentially contested concept", being "appraisive" (or considered as valued), "internally complex", and having relatively opens rules of application. Second, CSR is an umbrella term overlapping with some, and being synonymous with other, conceptions of businesssociety relations. Third, it has clearly been a dynamic phenomenon (Carroll, 1999, p.405). After several decades of studying CSR, McWilliams et al. (2006, p.8) strongly argue that; "there is a no strong consensus on a definition for CSR". The reasons given above are similar to those stated by Kakabadse et al. (2005), who also recognizes that CSR had often been associated other concepts, such as corporate social responsiveness and corporate social performance. Recent CSR literature has begun to consider business responsibilities to stakeholder society (particularly in newly emergent technologies) including global levels and commercial values. In this context, Carroll (1999) noted that CSR was known as social responsibility (SR) before the modern era of social responsibility began.

In his work, Sheehy has been defined by CSR as "international private business selfregulation" (Sheehy, 2015). Moreover, Sheehy's considered Carroll's description of CSR as a pyramid of responsibilities, namely, economic, legal, ethical, and philanthropic responsibilities (Carroll, 1991). While Carroll was not defining CSR, but simply arguing for classification of activities, therefore, Sheehy developed a definition differently following the philosophy of science as the part of philosophy which used for defining phenomena. However, Carroll extended CSR from the traditional economic and legal responsibility to ethical and philanthropic responsibility in response to the rising concerns on ethical issues in businesses (Carroll, 1991). Additionally, Baumann-Pauly et al. (2013) defined CSR as integration of environmental, social and ethical considerations into business conduct, often in line with the interests of stakeholders. The definition suggests that businesses not only operate for efficiency but also include accountability to stakeholders. One of the key tools to be considering the information to company stakeholders is through CSR reporting (Golob \& Bartlett 2007; Fifka, 2013; Sroka \& Szántó, 2018). 
The concept of CSR is now considered an umbrella term where challenging, harmonizing, and overlapping meanings such as corporate social performance, corporate citizenship, corporate social responsiveness, stakeholder management, ethical business practices, sustainable business practices, etc., are synonymously used to define CSR practices (Dahlsrud, 2008; Carroll \& Shabana, 2010). Dahlsrud (2008), during content analysis, analyze 37 definitions of CSR from twenty-seven authors and covered a time span from 1980 to 2003. He was able to develop five dimensions of CSR (i.e., environmental, social, economic, stakeholder and voluntaries). Most of these definitions focus on the content of CSR practices and what the organizations are doing as part of their social obligation to the society or the community. The process-based view suggests that

CSR practices could be seen as a 'convergence of interests' through win-win outcomes and creation process in the organization for both shareholders and other stakeholders (Carroll \& Shabana, 2010; Wang \& Juslin, 2011). However, Lu \& Castka (2009) suggest that a clear definition of CSR may help to extend diffusion and acceptance of CSR in developing country. In addition, they conclude that the implementation of CSR as requiring an effort in terms of time and it works in a long period.

In the new millennium corporations are increasingly receiving more pressures on compliance with regulations on environmental protection, transparency, and the business is saturated with competitors thereby necessitating the introduction of CSR as a strategy to survive and be more efficient (Galan, 2006). Thus, the spirit of engaging in CSR in the new millennium is tagged as "doing good to do well” (Rosamaria \& Robert, 2011). Rahman, (2011) gave a ten dimensional points on CSR definitions, which gives a full summary of all issues mentioned in various definitions of CSR such as: economic development, obligation to the society, improving the quality of life, stakeholder's involvement, human rights, law abiding, ethical business practice, voluntariness, environmental protection, transparency and accountability.

Finally, Masoud (2017) define CSR as "economic, glocal, legal and ethical, and philanthropic aspects of the CSR concept". This set of four responsibilities creates a foundation or infrastructure that helps to delineate in some detail and to frame or characterize the nature of businesses' responsibilities to the society of which it is a part. In 2017, Masoud resumed his work on CSR with an overview of the review begins with the historical roots of 
social responsibility and then explores the early stages of the formal and academic writing about the CSR and he goes through its evolution to the latest understanding of CSR concept. Considering that the concept of CSR such as corporate citizenship, corporate sustainability, business organization, stakeholder engagement and management. Masoud (2017) pointed out that all of these concepts have been included into CSR which is the reason why he defines it as the benchmark and central piece of the socially responsible business movement and changing. The table below summaries the scope /or dimensions of each definition of CSR from different periods.

Table 1: Dimensions of CSR Definitions

\begin{tabular}{l} 
Period \& Focus Area \\
1950's-1960's \\
- Unregulated philanthropy \\
- Community development \\
- Religious \& Humane philosophies \\
- Poverty alleviation \\
- Obligation to the society \\
1970's-1980's \\
- Stakeholders rights \\
- Cegal \& Ethical responsibilities \\
- Socio-economic priorities \\
- Extension of CSR commitments \\
- CSR as symbol of Corporate citizenship \\
- Stakeholder relationship management \\
1990's-21st Century \\
- Sustainability \\
- Competitive strategy \\
- Environmental protection \\
- Transparency \& accountability \\
\hline \hline
\end{tabular}

As long as definitions and concepts of CSR remain mostly theoretical and thus confined to the academic discussion, they are hardly useful in the long-run and do not contribute to what all of them actually demand; the obligation of corporations to take on social responsibilities. In sum, past studies defined CSR as going beyond a traditional role of sustainable business and involving extended accountability of organizations. At the same time, society is conveying the message to business that it is expected to obey the law and comply with regulations since law and regulations are society's codification of the basic 
ground rules upon which business is to operate in a civil society. If one come across at CSR in developing countries, for instance, whether a legal and regulatory framework exists or not significantly affects because such a legal infrastructure is very important to provide a foundation for legitimate business growth and sustainable.

\section{Scope and method of the review}

This section introduces the steps that were adopted to define CSR concept in UAE, it accounts CSR's main actors to provide a comprehensive overview of the practice in a specific context. The first step of definition development requires selection of scholar's work from the period of 1950s until update. This was followed up by primarily draws on secondary data sources with a view to compare and produce useful information of the literature sources collected. The authors will express the result obtained from this process and give an understanding interpretation on how the different literatures contribute to the existing body of knowledge of CSR. In a nutshell this paper is an overview of similarities and differences on CSR definitions, core characteristics and theories derived from review of different reliable literature review sources.

Therefore, based on the literature review, this study proposes the qualitative data framed the context of CSR added depth and subjectivity. Within CSR, the acknowledgement of culture and religion is particularly important to the society (Wood, 1991; Mehrdost, 2012; Munro, 2013). For instance, Islam prescribes a compulsory corporate and individual social responsibility (Rizk, 2008).

\section{The study context: UAE}

Since the establishment of UAE on 2 December 1971, the UAE shares a cultural and historical background with the MENA region (Kirk \& Napier, 2008), a geopolitical definition comprising nations and ethnicities characterised by a common language (Arabic) and religion (Islam) which operates on Shariah law. The UAE is a collectivistic society with a score of 25 (Hofstede, 1980, p.95), which presents large power distance, low future orientation and uncertainty avoidance (Hofstede, 1991).

UAE population increased during the past few years because of major growth in the various economic sectors from 69,558 in 1950 to $9,821,011$ million in 2019 according to UN data, 
and population is equivalent to $0.13 \%$ of the total world population, creating a multicultural society characterised by disparity and spatial segregation. The UAE citizens is around $11.5 \%$ and the remaining $88.5 \%$ made up of expatriate workers of the population, which lead to influx of workers from diverse cultural and religious background. Furthermore, expatriates include high-skilled professionals, although most are clustered in the lowest occupation categories, whilst $80 \%$ UAE occupy white collar positions. Majority of expats are short-term residents, a third medium-term, whilst less than $10 \%$ has more than 15 years of tenure. Most immigrants come from South Asian 59.4\% includes: (e.g., Indians 38.2\%, Pakistani 9.4\%, Bangladeshi 9.5\%, others 2.3\%), Egyptian 10.2\%, Filipino 6.1\%, other $12.8 \%$. Whilst female citizens and non-citizens account for $28 \%$ of the UAE'S population due to the high level of male foreign workers bonding occurs according to class, provenience, language, religion, or profession. The majority of the UAE population falls in the age group of (25 to 54) year old.

However, CSR in the MENA region presents characteristic roots and expressions that do not always mirror Western sympathetic and practice (Jamali, 2014). Thus, MENA follows the global CSR trend also as an extension of longstanding societal culture traditions (Shehadi et al., 2013).

On the other hand, many academics believe that CSR concepts are still new in this country and it is moving away from solely philanthropy and CSR awareness among organizations in the UAE is increasing (Al-Ali, 2007). In this environment, CSR of organizations and business is greatly tied to the cultural and Muslim traditions or religious of giving. Therefore, Kassis \& Majaj (2012) report that local companies work within and building on the wider culture, collective dynamics, and ethics of the region. In order to ensure that sustainable growth will not infuriate existing environmental concerns, government and businesses play an important role in making environmental policies to the society that are easily implemented and effective. One of the examples of social development program is the Sheikh Zayed Housing program aims to provide housing for UAE citizens, and on the other hand, Mohammed Bin Rashid housing establishment purpose is to provide enough housing for the citizens (Government of Dubai, 2012).

The UAE is categorized as one of the "rapidly developing economies" with particularly strong growth in recent years (Ronnegard, 2010). The UAE's economy is based on exports of natural resources, which is the world's seventh largest crude oil producer and the fourth 
largest producer of petroleum liquids in the Organization of the Petroleum Exporting Countries (OPEC). According to the UAE Central Bank's latest statistics, UAE's petroleum exports (hydrocarbons) grew by 13.9 percent to $\$ 66.2$ billion (AED 243.1 billion) in 2019 compared with \$58.1 billion (AED 213.5 billion) in 2017.

Within CSR, practices are prompted by multinational companies (MNCs) and local organizations adherence to best practices, because MNCs adopt the concept from their operations in the west or their headquarters (Zorzopulos, 2006). However, MNCs show more intention to be active towards CSR activities due to a more capable of adjusting to local situations and they practice those activities which are not different from the activities that local companies perform. The CSR guidelines are provided in order to integrate decisions and operations of the business with responsible practices. Furthermore, UAE has placed great emphasis in CSR to meet the ambitious goals which sets its path to sustainability on the four principles of economic, environmental, human, and social development. As recently as 1 , February, 2018, the CSR law imposes reporting requirements on contributions made to CSR activities and financial contributions, which provided additional policies regarding CSR. The regulation focuses on social, environmental and governance. It also offers various incentives to contribute to CSR initiatives and other philanthropic activities, donations contributions to charities and other social causes (Clyde \& Co, 2018). The objectives of the CSR Law are to:

1 .

2. establish a regulatory framework for CSR contributions in the UAE;

3. document, manage and direct CSR contributions made to UAE based CSR initiatives;

4. provide incentives and privileges for UAE businesses that contribute to CSR practices within the UAE;

5. establish the Federal Social Responsibility Fund, a new body to be created under the authority of the Ministry of Economy (the Fund); and

6. empower the Fund to promote a culture of social responsibility, including the preparation of a National Social Responsibility Index as an annual report to rank contributions made by UAE businesses to CSR in the UAE.

The CSR Law states that social responsibility is based on voluntary principles in UAE. However, CSR practices will remain voluntary, filing a CSR return and listing on the platform will become mandatory for all businesses in the UAE which fall within the scope of the CSR Law. Furthermore, the CSR Law points that the Fund will allow the companies and enterprises to use the social responsibility mark and permission for a defined period with stakeholders to form a list of benefits and privileges. Thus, benefits may include preference 
in government tenders, reduced fees and priority in government services. In addition, companies in the UAE should start reviewing their CSR activities with a view to making the appropriate disclosures for their trade license renewal. Brik (2009) believed that the government should take an active role in promoting CSR and more severe regulations are needed in the country. A recent initiative launched by Al Jalila Foundation in the UAE aims to raise AED 100 million for the year 2013 and to improve the health care services in the UAE.

Furthermore, there are many such initiatives in the UAE which have made the country more active among other Arab nations in terms of CSR and charitable activities. Society or community expects such gifts, but it does not label companies as "unethical" based on their giving patterns or whether the companies are giving at the preferred value level. As a consequence, the philanthropic responsibility is more discretionary or voluntary on business's dimensions. Therefore, this category is often thought of as good "corporate citizenship". Thus, historically philanthropy has been one of the most important elements of CSR definitions and this continues today as society expectations. Therefore, the needy people and it is considered in the UAE as 'Zakat' which is a voluntary distribution and Muslims donate to the needy people silently (Qasim et al., 2011).

The normative expectations of most societies hold that think about economic and business expectation as a social responsibility, but this is what it is because society expects, indeed requires, business organizations to be able to sustain themselves and the only way this is possible is by being to make money and able to engorge owners or shareholders to invest and have enough resources to continue in operation. Thus, society started views business organizations as institutions that will produce and sell the goods and services it needs and desires. As an encouragement, society allows businesses to take profits. Then businesses create profits when they add value, and in doing this they benefit all the stakeholders of the business. This means that business is to operate in a civil society has the expectation, and obligation, that it will do what is just, right, and fair and to avoid or minimize harm to all the stakeholders with whom it interacts.

In sum, it should be clearly stated that in addition to society's expectations regarding ethical performance, there are also the great, universal principles of moral philosophy such 
as justice, rights, and utilitarianism that also should inform and guide company decisions and business practices. Stated in more practical and managerial terms, the CSR driven organization should strive to make a profit, obey the law, engage in ethical practices and be a good corporate citizen (Carroll \& Buchholtz, 2015), and social activity can and does lead to economic rewards and that business should attempt to create such a good community expectation in UAE businesses. Qassim et al. (2011) mentioned that despite the awareness and perception of CSR practices and its benefits in UAE organizations is increasing but still advertising and promoting CSR activities in society is rare and lacking. However, results reveal that all most organizations now understand CSR but have failed to the traditional area of philanthropic giving. Employee health and safety, fair payment and discrimination found weak so they should be enforced. It implies that organizations are deficient in competencies to put CSR initiatives into practice.

\section{Discussion and conclusion}

The findings of this study align with literature, clearly indicating that a universal meaning for CSR may not be necessary as it is an essentially contested concept (Okoye, 2009), and there is still a need for a common reference point to clarify the CSR concepts. As the CSR community has become more watchful and social investment funds more demanding, the need for an overall index of progress on CSR has emerged. This common reference point will set the parameters of the issue and identify the common basis indicating that all such arguments relate to the CSR concept across national borders, and especially within UAE country.

As UAE is investing in social responsibility and sustainability, the CSR concepts assessed over time could help monitoring and evaluating progresses against the national agenda. As such, the CSR activities and the study findings open the opportunity for companies and governments not only to set their programme according to global and contextual elements, but also to analyse the sophistication and facets of their CSR involvement through longitudinal studies, in order to monitor performance and consistently target their strategic goals. In this sense, CSR is seen as a set of activities that work together through a consistent flow to relate with business, responsibilities, expectations, rights and regulations. 
UAE respondents appreciate the managerial dimension almost equally to the philanthropic one, whilst preserving it as part of their culture. Although, philanthropy is noted as a fundamental CSR dimension, respondents associate it to the religion, but also to an early stage of the development. In this sense, while CSR makes room for different voices, with wide-ranging interests in the achievement of an appropriate relationship between corporation and society. To some stakeholders, CSR conveys the idea of socially responsible behavior; to others, it means legal responsibility or liability; to yet others, CSR are just a tool to transmit a "responsible for" message from organizations to society at large.

The results of this study and its implications advocate further research in various fields. The findings support the importance of CSR practices and community expectations, especially in the UAE country. However, future research into this should the examination of differences between the national bodies' understanding and definitions of CSR and practitioners. The single developing country in which this study was conducted implies a limited generalisability of these results and thus future research may be of interest to a broad country and other related literatures to conduct research in CSR practices.

\section{Competing interests}

The authors declare that he has no competing interests.

\section{References}

Aguinis, H., \& Glavas, A. (2012). What we know and don't know about corporate social responsibility: A review and research agenda. Journal of Management, 38(4), 932968.

Aguinis, H., \& Glavas, A. (2019). On corporate social responsibility, sensemaking, and the search for meaningfulness through work. Journal of Management, 45(3), 10571086. DOI: $10.1177 / 0149206317691575$.

Al-Ali, J. (2007). Emiratisation: drawing UAE nationals into their surging economy. International Journal of Sociology and Social Policy, 28 (9/10), 365-379.

Ardichvili, A., Jondle, D., Kowske, B., Cornachione, E., Li, J., \& Thakadipuram, T. (2012). Ethical cultures in large business organisations in Brazil, Russia, India, and China. Journal of Business Ethics, 105(4), 415-428.

Baumann-Pauly, D., Wickert, C., Spence, L.J., \& Scherer, A.G. (2013) Organizing corporate social responsibility in small and large firms: size matters. Journal of Business Ethics, 115, 693-705. https://doi. org/10.1007/s10551-013-1827-7. 
Bentele, G., \& Nothhaft, H. (2011). Trust and credibility as the basis of corporate social responsibility (mass-) mediated construction of responsibility and accountability. In $\varnothing$. Ihlen, J.L. Bartlett, \& S. May (Eds.), The handbook of communication and corporate social responsibility (pp. 208-229). Chichester: Wiley Blackwell Ch. 11.

Blomgren A. (2011). Does corporate social responsibility influence profit margin? A case study of executive perceptions. Corporate Social Responsibility and Environmental Management. DOI: 10.1002/csr.246.

Blowfield, M., \& Frynas, J. G. (2005). Setting new agendas: Critical perspectives on corporate social responsibility in the developing world. International Affairs, 81(3), 499-513.

Blowfield, M., \& Murray, A. (2008). Corporate responsibility: A critical introduction. Oxford University: Oxford.

Bowen, H. (1953). Social responsibilities of the businessman, Harper, New York.

Brik, A. (2009). Toward Green Economy in the United Arab Emirates: Responsible Business and Sustainable Consumption. [Online]. [Accessed 25 November 2019]. Available at: http://csrarabia.wordpress.com/2009/10/28/toward-green-economy-inthe-unitedarab-emiratesresponsible-business-and-sustainable-consumption.

Brik, A., Rettab, B., \& Mellahi, K. (2010). Market orientation, corporate social responsibility and business performance. Journal of Business Ethics DOI:10.1007/s10551-010$0658 \mathrm{z}$.

Carroll, A.B. (1991). The pyramid of corporate social responsibility: Toward the moral management of organizational stakeholders. Business Horizons, 34(4), 3948. doi:10.1016/0007-6813(91)90005-g.

Carroll, A. B. (1999). Corporate social responsibility: Evolution of definitional construct. Business and Society, 38(3), 268-295.

Carroll, A. B., \& Buchholtz, A. K. (2015). Business and society: Ethics, sustainability and stakeholder management ( $9^{\text {th }}$ ed.). Stamford: Cengage Learning.

Carroll, A.B., \& Shabana, K.M. (2010). The business case for corporate social responsibility: A review of concepts, research and practice. International journal of management reviews, 12(1), 85-105.

Chomvilailuk, R., \& Butcher, K. (2013). The effect of CSR knowledge on customer liking, across cultures. International Journal of Bank Marketing,31(2), 98-114.

Clyde \& Co, (2018). CSR Law in the UAE: Are you ready? [Online]. [Accessed 28 November 2019]. Available at: https://www.clydeco.com/insight/article/uaecorporate-social-responsibility-law-areyou-ready.

de Bakker, F.G.A., Groenewegen, P., \& den Hond, F. (2006). A Research note on the use of bibliometrics to review the corporate social responsibility and corporate social performance literature. Business and Society, 45(1), 7-19.

Dahlsrud, A. (2008). How corporate social responsibility is defined: An analysis of 37 definitions. Corporate Social Responsibility and Environmental Management, 15, 113.

Davis, T.A. (1973). A social movement perspective on corporate control. Administrative Science Quarterly, 39, 141-173. 
Davis, K., \& Blomstrom, R.L. (1975). Business and society: Environment and responsibility. $\left(3^{\text {rd }}\right.$ ed). New York: McGraw-Hill.

De George, R.T. (2011). Business ethics. dorling kindersley, licensees of Pearson education in South Asia. ISBN 978-81-317-6335-3.

Diehl, S., Terlutter, R., Mueller , B. (2016). Doing good matters to consumers: The effectiveness of humane-oriented CSR appeals in cross-cultural standardized

advertising campaigns. Int. J. Adver, 35(4), 730757, 10.1080/02650487.2015.1077606.

Dobers, P., \& Halme, M. (2009). Corporate social responsibility and developing countries. Corp. Soc. Responsib. Environ. Manag, 16, 237-249.

Drucker, P.F. (1954). The Practice of Management. Collins, New York USA.

Egri, C.P., \& Ralston, D.A. (2008). Corporate responsibility: A review of international management research from 1998 to 2007. Journal of International Management, 14(4), 319-339.

El Akremi, A., Gond, J.P., Swaen, V., De Roeck, K., \& Igalens, J. (2018). How do employees perceive corporate social responsibility? Development and validation of a multidimensional corporate stakeholder responsibility scale. Journal of Management, 44, 619-657.

Falck, O., \& Heblich, S. (2007). Corporate social responsibility: Doing well by doing good. Business Horizons, 50, 247-254.

Fifka, M.S. (2013). Corporate responsibility reporting and its determinants in comparative perspective -a review of the empirical literature and a meta-analysis. Business Strategy and the Environment, 22(1), 1-35. doi: 10.1002/bse.729.

Frederick, W.C. (2006). Corporation, be good! The story of corporate social responsibility. Indianapolis: Dog Ear Publishing.

Frynas, J.G., \& Yamahaki, C. (2016). Corporate social responsibility: Review and roadmap of theoretical perspectives. Business Ethics: A European Review, 25(3), 258-285.

Galan, J.I. (2006). Corporate social responsibility and strategic management. Journal of Management Studies, 43(7), 1629-41.

Golob, U.A., \& Bartlett, J.L. (2007). Communicating about corporate social responsibility: A comparative study of CSR reporting in Australia and Slovenia. Public Relations Review, 33(1), 1-9. Government of Dubai. (2012). CSR in Dubai. [online]. [Accessed 1 December 2019]. Available at: http://www.dubai.ae/en/Lists/Topics/DispForm.aspx?ID=30\&category=Home.

Grafström, M., \& Windell, K. (2011). The role of infomediaries: CSR in the business press during 2000-2009. Journal of Business Ethics, 103(2), 221-237.

Halme, M., \& Laurila, J. (2009). Philanthropy, integration, or innovation? Exploring the financial and social outcomes of different types of corporate responsibility. Journal of Business Ethics, 84, 325-339.

Hofstede, G. (1980). Culture and organisations. International Studies of Management and Organisation, 10(4), 15-41.

Hofstede, G. (1991). Management in a multicultural society. Malaysian Management Review, 26(1), 3-12.

Idemudia, U. (2011). Corporate social responsibility and developing countries. Progress in Development Studies, 11(1), 1-18. 
Jackson, G., \& Apostolakou, A. (2010). Corporate social responsibility in Western Europe: An institutional mirror or substitute? Journal of Business Ethics, 94, 371-394.

Jamali, D. (2014). Overview of corporate social responsibility in the Middle East: Global business. World Financial Review, 71-72.

Jamali, D., \& Neville, B. (2011). Convergence versus divergence of CSR in developing countries: An embedded multi-layered institutional lens. Journal of Business Ethics, $102,599-621$.

Kakabadse, N. K., Rouzel, C., \& Lee-Davies, L. (2005). Corporate social responsibility and stakeholder approach: A conceptual review. International Journal of Business Governance and Ethics, 1(4), 277-302.

Kang, N., \& Moon, J. (2011). Institutional complementarity between corporate governance and corporate social responsibility: A comparative institutional analysis of three capitalisms. Socio-Economic Review, 10, 85-108.

Jamali, D., \& Karam, C. (2018). Corporate social responsibility in developing countries as an emerging field of study. International Journal of Management Reviews, 20(1), 3261.

Kassis, S., \& Majaj, Y. (2012). CSR and philanthropy: Different forms of effective social investment. CSR in the Middle East: Fresh Perspectives 11.

Kirk, D., \& Napier, D. (2008). The transformation of higher education in the UAE: Issues, implications and intercultural dimensions. In J.Zajda, H. Daun, \& L.J. Saha (Eds.), Nation-building, identity and citizenship education: Cross cultural perspectives (pp. 131-142).Springer.

Lockett, A., Moon, J., \& Visser, W. (2006). Corporate social responsibility in management research: Focus, nature, salience and sources of influence. Journal of Management Studies, 43(1), 115-136.

Lu, J., \& Castka, P. (2009). Corporate social responsibility in Malaysia -experts' views and perspectives. Corporate Social Responsibility and Environmental Management, 16, 146154.

Masoud, N. (2017). How to win the battle of ideas in corporate social responsibility: The international pyramid model of CSR. International Journal of Corporate Social Responsibility, 2(4), 1-22. doi.org/10.1186/s40991-017-0015-y.

Matten, D., \& Moon, J. (2008). 'Implicit' and 'explicit' CSR: A conceptual framework for understanding CSR in Europe. Academy of Management Review, 33(2), 404-424.

McGuire, A. (1963). It was nothing. Extending evolutionary models of altruism by two social cognitive biases in judgments of the costs and benefits of helping. Social Cognition, 21(5), 363-384.

McWilliams, A., Siegel, D.S., \& Wright, P.M. (2006). Corporate social responsibility: International perspectives. Rensselaer working papers in economics. NewYork, USA: Rensselaer Polytechnic Institute Available from: http://www.economics.rpi.edu/workingpapers/rpi0604.pdf. Accessed 10.November 2019.

Mehrdost, H. (2012). Strategies to promote social responsibility in cultural organisations. International Journal of Business and Social Science, 3(6), 236-242.

Metaxas, T., \& Tsavdaridou, M. (2010). Corporate social responsibility in Europe: Denmark, Hungary and Greece. Journal of Contemporary European Studies, 18(1), 25-46. 
Moon, J., Crane, A., \& Matten, D. (2005). Can corporations be citizens: Corporate citizenship as a metaphor for business participation in society. Business Ethics Quarterly, 15(3), 429.

Moon, J., \& Shen, X. (2010). CSR in China research: Salience, focus and nature. Journal of Business Ethics . doi:10.1007/s10551-009-0341-4.

Moon H-C, Parc, J. (2019). Shifting corporate social responsibility to corporate social opportunity through creating shared value. Strategic Change, 28(2), 115-122. https://doi.org/10.1002/jsc.2252.

Munro, V. (2013). Stakeholder understanding of corporate social responsibility (CSR) in emerging markets with a focus on Middle East, Africa (MEA) and Asia. Journal of Global Policy and Governance, 2(1), 59-77.

Okoye, A. (2009). Theorising Corporate Social Responsibility as an Essentially Contested Concept: Is a Definition Necessary? Journal of Business Ethics, 89(4), 613.

Parker, S.C. (2018).The economics of entrepreneurship. Cambridge University Press: Cambridge, UK.

Qasim, Z., Muralidharan, P\& Ramaswamy, G. (2011). Corporate social responsibility and impact of CSR practices in the United Arab Emirates: International Conference on Technology and Business Management. Shaheed Zulfikar Ali Bhutto Institute of Science and Technology. Dubai. 28-30 March.

Quazi, A. M., \& O'Brien, D. (2000). An empirical test of a cross-national model of corporate social responsibility. Journal of Business Ethics, 25(1), 33-51.

Rahman, S. (2011). Evaluation of definitions: Ten dimensions of corporate social responsibility. World Review of Business Research, 1(1), 166-176.

Rizk, R. (2008). Islam and corporate governance. In G. Aras, \& D. Crowther (Eds.), Culture and corporate governance research series: Issues in corporate behaviour and sustainability (pp. 204-214). Leicester: Social Responsibility Network.

Ronnegard, D. (2010). Corporate social responsibility and the United Arab Emirates. pp.317 [ Accessed 2 December 2019]. Available at: www.sdg-int.org/uploads/csr-andtheuae-final.pdf.

Rosamaria, C.M., \& Robert, C.P. (2011). Historical background of corporate social responsibility. Social Responsibility Journal, 7(4), 528-539.

Ruggiero, P.; Cupertino, S.; Ruggiero, P., \& Cupertino, S. (2018). CSR strategic approach, financial resources and corporate social performance: The mediating effect of innovation. Sustainability, 10, 3611.

Secchi, D. (2007). Utilitarian, managerial and relational theories of corporate social responsibility. International Journal of Management Reviews, 9(4), 347-373.

Sheehy, B. (2015). Defining CSR: Problems and solutions. Journal of Business Ethics. 131(3), 625-648. doi:10.1007/s10551-014-2281-x.

Shehadi, R., Ghazaly, S., Jamali, D., Jamjoom, M., \& Insight, I.C. (2013). The rise of corporate social responsibility a tool for sustainable development in the Middle East. Booz \& Company Available from: http://static.wamda.com/web/uploads/resources/BoozCo_The-Rise-of-Corporate Social-Responsibility.pdf. Accessed 20.07.15. 
Sroka, W., \& Szántó, R. (2018). Corporate social responsibility and business ethics in controversial sectors: Analysis of research results. J. Entrep. Manag. Innov, 14, 111-126.

Taneja, S.S., Taneja, P.K., \& Gupta, R.K. (2011). Researches in corporate social responsibility: A review of shifting focus, paradigms, and methodologies. Journal of Business Ethics, 101(3), 343-364. http://dx.doi.org/10.1007/s10551-010-0732-6

Visser, W. (2008). Corporate social responsibility in developing countries. In A. Crane, D. McWilliams, J.M. Matten, \& D. Siegel (Eds.), The Oxford handbook of corporate social responsibility (pp. 473-479). Oxford, UK: Oxford University.

Walter, W., \& Sharyn. R.R. (2017). Inclusion of ethics, social responsibility, and sustainability in business school curricula: a benchmark study. International Review on Public and Nonprofit Marketing, 14(1), 19-34.

Walton, C. (1967). Corporate Social Responsibilities. Belmont, CA: Wadsworth.

Wang L., \& Juslin, H. (2011). Corporate social responsibility in the Chinese forest industry: Understanding multiple stakeholder perceptions. Corporate Social Responsibility and Environmental Management DOI: 10.1002/csr.286.

Welford, R. (2004). Corporate social responsibility in Europe and Asia: Critical elements and best practice. Journal of Corporate Citizenship, 13, 31-47.

Wood, D. (1991). Toward improving corporate social performance. Business Horizons, 34(4), 66-73.

Zorzopulos, S. (2006) Corporate social responsibility in the United Arab Emirates: A Preliminary Assessment, Dubai Ethics Resource Center. 